\title{
Identifikasi Keragaman Gen TGF- $\beta 2$ dan Asosiasinya dengan Sifat Pertumbuhan pada Ayam Tolaki
}

\author{
Identification of TGF- $\beta 2$ General Diversity and Its Association with Growth Properties in Tolaki Chicken \\ M. Akramullah ${ }^{1 *}$, C. Sumantri ${ }^{2}$, N. Ulupi ${ }^{2}$, \& M. A. Pagala ${ }^{3}$ \\ ${ }^{1}$ Mahasiswa Program Studi Ilmu Produksi dan Teknologi Peternakan, Sekolah Pascasarjana, IPB. \\ ${ }^{2}$ Departemen Ilmu Produksi dan Teknologi Peternakan, IPB. \\ ${ }^{3}$ Fakultas Peternakan, Universitas Halu Oleo, Kendari. \\ *Email koresponden author: muhakramullah44@gmail.com \\ (Received 16-12-2019; Revised 30-12-2019; Accepted 10-01-2020)
}

\begin{abstract}
The transforming growth factor-beta 2 (TGF-ß2) gene is a group of growth hormone (GH) genes that control the nature of growth and belongs to the cytokine group. This study aimed to identify Single Nucleotide Polymorphism (SNP) g.640 T $>$ C from the TGF- 32 gene then associated with the growth properties of tolaki chickens. Chicken blood samples used in this study amounted to 70 birds. Data on the nature of growth observed include; hatched weight, feed consumption, body weight, body weight gain and feed conversion. The TGF- $\beta 2$ gene polymorphism was identified using the PCR-RFLP method. SNP g.640 $\mathrm{T}>\mathrm{C}$ in the TGF- $\beta 2$ gene was polymorphic and wasin Hardy-Weinberg balance. Identification results found 2 alleles, namely $T$ and $C$ and 3 genotype namely TT, TC, and CC. The association of TGF- 32 gene diversity in tolaki chicken generally showed a difference $(\mathrm{P}<0.05)$ on feed consumption, body weight and body weight gain. CC genotype has higher feed consumption, body weight, weight gain and more efficient feed conversion than TC and TT genotypes.
\end{abstract}

Keywords: PCR-RFLP, SNP (640) T>C, TGF- $\beta 2$ gene, tolaki chicken

\begin{abstract}
ABSTRAK
Transforming growth factor-beta 2 (TGF-ß2) adalah kelompok gen growth hormone (GH) yang mengontrol sifat pertumbuhan dan termasuk dalam kelompok sitokin. Penelitian ini bertujuan untuk mengidentifikasi Single Nucleotide Polymorphism (SNP) g.640 T $>$ C pada gen TGF- $\beta 2$ yang diasosiasikan dengan sifat pertumbuhan ayam tolaki. Sampel darah ayam yang digunakan dalam penelitian ini berjumlah 70 ekor. Data tentang sifat pertumbuhan yang diamati meliputi; bobot tetas, konsumsi pakan, bobot badan, pertambahan bobot badan dan konversi pakan. Polimorfisme gen TGF- $\beta 2$ diidentifikasi menggunakan metode PCR-RFLP. SNP g.640 T>C pada gen TGF- 32 bersifat polimorfik dan berada dalam keseimbangan Hardy-Weinberg. Hasil identifikasi ditemukan 2 alel, yaitu $\mathbf{T}$ dan $\mathrm{C}$ dan 3 genotipe yaitu TT, TC, dan CC. Asosiasi keragaman gen TGF-ß2 pada ayam tolaki umumnya menunjukkan perbedaan $(\mathrm{P}<0,05)$ pada konsumsi pakan, berat badan dan pertambahan bobot badan. Genotipe $\mathrm{CC}$ memiliki konsumsi pakan, berat badan, pertambahan bobot lebih tinggi dan konversi pakan yang lebih efisien dari pada genotipe TC dan TT.
\end{abstract}

Kata kunci: PCR-RFLP, SNP (640) T>C, gen TGF-ß2, ayam tolaki

\section{PENDAHULUAN}

Ayam tolaki merupakan salah satu ayam asli Indonesia yang tersebar khususnya di wilayah Sulawesi Tenggara dan umumnya dipelihara oleh masyarakat suku Tolaki. Berdasarkan karakter fenotipenya ayam tolaki memiliki pola warna bulu dan sifat agresif yang mirip dengan ayam hutan merah (Gallus-gallus) (Pagala et al. 2018). Selain itu diduga kuat ayam tolaki merupakan hasil persilangan dari ayam kampung dan ayam hutan, hal ini dikarenakan pemukiman penduduk suku Tolaki yang berdekatan dengan wilayah hutan (Aku et al. 2010). Ayam tolaki sering digunakan untuk kepentingan acara adat yang berlangsung di suku Tolaki (Rusdin et al. 2011). Kabupaten 
Konawe, Konawe Selatan dan Kolaka merupakan lokasi asal ayam tolaki di Provinsi Sulawesi Tenggara.

Menurut Nafiu et al. (2009), ayam tolaki merupakan ayam tipe dwiguna yaitu penghasil telur dan daging. Ayam tolaki selama 1 periode mampu menghasilkan telur sebanyak 25.47 butir ekor $^{-1}$, lebih tinggi dibandingkan dengan ayam kampung yaitu 10.55 butir ekor ${ }^{-1}$ (Nafiu et al. 2012). Bobot badan ayam tolaki jantan dewasa mencapai 1.4-1.8 $\mathrm{kg}$ ekor $^{-1}$ dan ayam betina dewasa 0.6-1.6 kg ekor ${ }^{-1}$ (Sulandari et al. 2007). Tingkah laku ayam tolaki termasuk dalam kategori ayam yang agresif (Pagala et al. 2018). Ayam tolaki tergolong tahan terhadap penyakit Newcastle Disease yang disebabkan oleh virus (Pagala et al. 2013). Adapun kelemahan ayam tolaki antara lain memiliki pertumbuhan yang lambat. Bobot badan ayam tolaki dewasa lebih rendah dibandingkan dengan ayam kampung dan ayam sentul (Sulandari 2007).

Laju pertumbuhan dapat ditingkatkan melalui seleksi yang terarah menggunakan penanda molekuler berbasis MAS (Marker Assissted Selection) yang terbukti dapat meningkatkan respon seleksi pada keturunan (Sartika et al. 2004). MAS dapat diperoleh melalui identifikasi gen-gen utama yang mengontrol sifat pertumbuhan pada ayam. Salah satu gen yang memegang peranan penting dalam mengontrol sifat pertumbuhan pada ayam adalah gen TGF- $\beta 2$ (transforming growth factor-beta2).

Gen TGF- $\beta 2$ termasuk kelompok gen GH dan kelompok gen sitokin (Susan 2011). Sitokin merupakan jenis protein yang terlibat dalam komunikasi sel-sel sebagai mediator untuk meningkatkan respon imun (Wibawan dan Soejoedono 2013). Gen ini merupakan salah satu superfamili gen TGF- $\beta$, yang memainkan peran penting dalam diferensiasi sel, perkembangan otot dan pertumbuhan. TGF- $\beta 2$ penting dalam banyak proses perkembangan; misalnya, tikus dengan penghapusan gen TGF- $\beta 2$ menunjukkan cacat dalam pengembangan sistem jantung, paru, kraniofasial, ekstremitas, mata dan telinga (Dunker dan Kreiglstein 2002).

Gen TGF- $\beta 2$ pada ayam terletak di kromosom 3 dan memiliki ukuran 64065 pb. Berdasarkan strukturnya, gen TGF- $\beta 2$ terdiri dari wilayah promotor, exon, intron dan flanking region (NCBI 2018). Hasil penelitian terdahulu menyebutkan bahwa genTGF- $\beta 2$ bersifat polimorfik pada ayam sentul (Muhsinin et al. 2017), pada ayam lokal Malaysia (Tohidi et al. 2012), dan pada ayam Broiler (Kramer et al. 2003). Adanya mutasi ada daerah exon dengan panjang 284 pb membentuk beberapa genotipe. Variasi genotipe tersebut mempengaruhi sifat pertumbuhan pada ayam (Tohidi et al. 2012; Niarami et al. 2014).

Penelitian ini bertujuan untuk mengkaji keragaman gen TGF- $\beta 2$ dan asosiasinya dengan sifat pertumbuhan. Hasil penelitian ini diharapkan memperoleh informasi ilmiah tentang keragaman gen TGF- $\beta 2$ pada ayam tolaki. Ditemukan kandidat gen yang mengontrol sifat pertumbuhan.

\section{MATERI DAN METODE}

Waktu dan Tempat Penelitian

Penelitian ini dilaksanakan di Kandang Unit Unggas Fakultas Peternakan Universitas Halu Oleo, Kendari dan di Laboratorium Genetika Molekuler Bagian Pemuliaan dan Genetika, Departemen Ilmu Produksi dan Teknologi Peternakan, Fakultas Peternakan, Institut Pertanian Bogor. Penelitian ini berlangsung dari Oktober 2018 sampai bulan Agustus 2019.

\section{Materi Penelitian}

Ayam tolaki yang digunakan dalam penelitian ini berjumlah 70 ekor diperoleh dari hasil penetasan. Telur tetas didapatkan dari indukan ayam tolaki yang diambil di masyarakat Kabupaten Konawe Selatan. Pemeliharaan ayam tolaki dari umur 0 hari sampai dengan umur 12 minggu. Jenis pakan yang diberikan adalah pakan komersial dengan kandungan protein kasar sebesar 17\% dan energi metabolis sebesar $2950 \mathrm{kkal} \mathrm{kg}^{-1}$. Pakan diberikan 2 kali sehari pukul 06.00 WITA dan pukul 16.00 WITA.

\section{Prosedur}

Penelitian ini terdiri dari 2 tahap. Tahap pertama adalah genotyping gen TGF- $\beta 2$. Tahap kedua adalah mengasosiasikan genotipe gen TGF- $\beta 2$ dengan sifat pertumbuhan.

\section{Penelitian Tahap I : Genotyping Gen TGF- $\beta 2$}

Penelitian pada tahap ini, bertujuan untuk mengidentifikasi keragaman gen TGF- $\beta 2$. Diawali dengan pengambilan sampel darah, ekstraksi DNA, Amplifikasi Polymerase Chain Reaction (PCR), Analisis Restriction Fragment Lenght Polymorphism (RFLP) dan elektroforesis produk PCR-RFLP.

\section{Pengambilan Sampel Darah}

Pada akhir minggu ke-12 dilakukan pengambilan darah pada vena brachialis di daerah sayap. Pengambilan darah ini digunakan sebagai sampel untuk genotyping. Pengambilan darah dilakukan menggunakan spuit $1 \mathrm{~mL}$ sebanyak $0.5-1 \mathrm{~mL}$.

\section{Ekstraksi DNA dan Amplifikasi Gen TGF-ß2}

Ekstraksi DNA dilakukan dengan menggunakan metode phenol-choroform (Sambrook dan Russel 2001). Amplifikasi fragmen gen TGF- $\beta 2$ dilakukan dengan metode Amplifikasi Polymerase Chain Reaction (PCR). Primer didisain pada titik mutasi SNP (640) $\mathrm{T}>\mathrm{C}$ di exon 1 dengan panjang sekuen target adalah 284 pb dengan bantuan Primer Designing Tools Program (http://www.ncbi.nlm. nih.gov/tools/primer-blast). Reaksi primer menggunakan forward (F: 5'GGTTCAGTGCAAGGCATTTC 3') dan primer reverse (R: 5'CTTCTGTCAAGTGCAGTGAG 3') (Muhsinin et al. 2018). Posisi penempelan primer pada fragmen gen TGF- $\beta 2$ disajikan pada Gambar 1 .

Amplifikasi DNA dilakukan pada total volume 15 $\mu \mathrm{L}$, terdiri dari $1 \mu \mathrm{L}$ DNA, $10.85 \mu \mathrm{L}$ DW, $0.30 \mu \mathrm{L}$ primer, $0.05 \mu \mathrm{L}$ Taq polymerase, $1.50 \mu \mathrm{L}$ buffer, $0.30 \mu \mathrm{L}$ dNTP dan $1.00 \mu \mathrm{L} \mathrm{MgCl2}$. Campuran pereaksi dimasukkan ke dalam tabung $1.50 \mu \mathrm{L}$ untuk dihomogenkan, kemudian 
reverse

$\operatorname{SNP}(640)=$ GGTAC

Produk $\mathrm{PCR}=289$
Alel T (restricted) $=5$ '....... TACGGTACAAG........3'

Alel C (unrestricted) $=5$ ' ...... TACGGCACAAG .......3'

Gambar 1. Posisi penempelan primer pada fragmen gen TGF- $\beta 2$ exon 1 dan situs pemotongan enzim Rsal

didistribusikan ke masing-masing tabung yang berisi sampel DNA dan selanjutnya dimasukkan ke dalam mesin PCR. Amplifikasi DNA berlangsung di dalam mesin PCR Applied Biosystems dengan kondisi suhu predenaturasi 95 ${ }^{\circ} \mathrm{C}$ selama 5 menit, siklus untuk tahapan denaturasi pada suhu $95{ }^{\circ} \mathrm{C}$ selama 10 detik, annealing pada suhu $60{ }^{\circ} \mathrm{C}$ selama 20 detik dan elongasi pada suhu $72{ }^{\circ} \mathrm{C}$ selama 30 detik, kemudian dengan tahap elongasi akhir pada suhu $72{ }^{\circ} \mathrm{C}$ selama 5 menit dalam 1 siklus. Produk PCR dielektroforesis menggunakan gel agarosa $1.5 \%$.

\section{Analisis Restriction Fragment Lenght Polymorphism (RFLP) gen TGF- $\beta 2$}

Penentuan genotipe gen TGF- $\beta 2$ pada ayam tolaki menggunakan metode RFLP. Produk amplifikasi dari gen TGF- $\beta 2$ dipotong dengan menggunakan enzim restriksi. Enzim restriksi dirancang berdasarkan SNP yang telah ditemukan pada gen TGF- $\beta 2$ dengan program NEBcutter V2.0. RsaI merupakan enzim restriksi yang digunakan untuk memotong SNP gen TGF- $\beta 2$ pada situs GT $\mid$ AC. Sebanyak $5 \mu \mathrm{L}$ produk PCR dipindahkan ke dalam tabung $0.5 \mathrm{~mL}$ yang ditambahkan $0.9 \mu \mathrm{L} \mathrm{DW}, 0.4 \mu \mathrm{L}$ enzim $R s a I$ dan $0.7 \mu \mathrm{L}$ buffer. Campuran tersebut diinkubasikan pada suhu $37^{\circ} \mathrm{C}$ selama kurang lebih 16 jam (overnight).

\section{Elektroforesis Produk PCR-RFLP gen TGF- $\beta 2$}

Produk PCR-RFLP dielektroforesis menggunakan gel agarose dengan kosentrasi 2\%. Sebanyak 0.6 gagarose ditambahkan dengan $30 \mathrm{~mL} 0.5$ x TBE (Tris Borat EDTA). Campuran tersebut dipanaskan dalam microwave selama 5 menit, dikocok dengan magnetic stirrer, ditambahkan $1 \mu \mathrm{L}$ fluorosafe, dan dicetak sehingga terbentuk sumursumur di dalam gel. Marker DNA 100 bp sebanyak $2 \mu \mathrm{L}$ dimasukkan ke dalam sumur paling kiri sebagai penanda. Masing-masing sampel DNA hasil PCR sebanyak $5 \mathrm{~mL}$ dimasukkan ke dalam sumur gel. Gel dialiri listrik $100 \mathrm{~V}$ selama 30 menit. Setelah elektroforesis selesai, gel difoto menggunakan mesin UV-Transilluminator.

\section{Analisis Data}

Setelah genotipe didapat melalui metode PCR-RFLP, nilai frekuensi genotipe, frekuensi alel, heterozigositas pengamatan, heterozigositas harapan dan nilai keseimbangan Hardy-Weinberg dihitung berdasarkan rumus berikut:
1. Frekuensi alel (Nei dan Kumar 2000)

Frekuensi alel, yaitu proporsi atau persentase alel tertentu pada suatu lokus.

$$
\chi_{i}=\frac{\left(2 n i i+\sum_{j \neq 1} n i j\right)}{(2 N)}
$$

Keterangan :

$\chi \mathrm{i} \quad=$ frekuensi alel ke-i;

nii $=$ jumlah individu bergenotipe ii;

nij = jumlah individu bergenotipe ij; dan

$\mathrm{N}=$ total sampel.

2. Frekuensi Genotipe (Nei dan Kumar 2000)

Frekuensi genotype, yaitu proporsi atau persentase genotipe tertentu di dalam suatu populasi.

$$
\chi_{\mathrm{ii}}=\frac{\sum_{i=1}^{n} n i}{(N)}
$$

Keterangan :

$\chi$ ii $=$ frekuensi genotype ke-i;

$\mathrm{Ni}=$ jumlah individu bergenotipe ii; dan

$\mathrm{N}=$ total sampel.

3. Heterosigositas (Nei dan Kumar 2000)

Perhitungan heterosigositas dilakukan untuk mengetahui keragaman genetik dalam suatu populasi. Perhitungan heterosigositas pengamatan dan heterosigositas harapan dianalisis berdasarkan rumus Nei dan Kumar (2000) sebagai berikut:

$$
\text { Ho }=\sum_{i \neq j} \frac{N_{1 j k}}{N} \quad \mathrm{He}=1-\sum_{i=1}^{n} P_{1 i}{ }^{2}
$$

Keterangan :

Ho = heterosigositas pengamatan;

Nijk = jumlah individu heterosigot pada lokus ke-1;

$\mathrm{He}=$ heterosigositas harapan; dan

P1i = frekuensi alel ke-1.

$\mathrm{N}=$ total sampel

4. Keseimbangan Hardy-Weinberg (Hartl dan Clark 1997) Keseimbangan Hardy-Weinberg, yaitu kesetimbangan frekuensi alel dan frekuensi genotipe dalam suatu populasi. 


$$
\chi^{2}=\sum \frac{(0-\mathrm{E})^{2}}{\mathrm{E}}
$$

Keterangan :

$$
\begin{array}{ll}
\chi^{2} & =\text { nilai chi-square } \\
\mathrm{O} & =\text { jumlah genotype teramati; dan } \\
\mathrm{E} & =\text { jumlah genotype harapan. }
\end{array}
$$

\section{Penelitian Tahap II : Asosiasi Gen TGF-ß2 dengan Sifat Pertumbuhan}

\section{Pemeliharaan}

Ayam tolaki yang digunakan dalam penelitian ini berjumlah 70 ekor. Pemeliharaan dari DOC umur 0 hari sampai dengan umur 2 minggu. Sebelum dimasukkan ke dalam kandang terlebih dahulu dilakukan penimbangan bobot badan dan pemberian nomor kaki. Penimbangan dilakukan setelah bulu kering.

Pada umur 3-12 minggu ayam ditempatkan pada petak individu (sangkar), yang telah diberi nomor di setiap petak. Ukuran sangkar sekitar $35 \mathrm{~cm} \mathrm{x} 35 \mathrm{~cm}$ x 40 $\mathrm{cm}$. Sangkar tersebut ditempatkan dalam kandang yang berukuran $5 \mathrm{~m}$ x $15 \mathrm{~m}$.

Jenis pakan yang diberikan adalah pakan komersial PAR-G dengan kandungan protein kasar sebesar 17\% dan energi metabolis sebesar $2950 \mathrm{kkal} \mathrm{kg}^{-1}$. Pakan diberikan 2 kali sehari pukul 06.00 WITA dan pukul 16.00 WITA. Ayam ditimbang setiap minggu untuk mengetahui pertambahan bobot badan yang dihasilkan selama pemeliharaan.

Pada akhir minggu ke-12 dilakukan pengambilan darah pada vena brachialis di daerah sayap. Pengambilan darah ini digunakan sebagai sampel untuk genotyping. Pengambilan darah dilakukan menggunakan spuit $1 \mathrm{~mL}$ sebanyak 0.5-1 mL.

\section{Peubah yang diamati}

Peubah yang diamati dalam penelitian ini meliputi:

1. Bobot tetas $\left(\mathrm{g} \mathrm{ekor}^{-1}\right)$ merupakan bobot anak ayam saat menetas, kemudian ditimbang setelah bulu anak ayam kering;

2. Konsumsi pakan (g ekor ${ }^{-1}$ ) diukur berdasarkan jumlah pakan yang diberikan setiap hari dikurangi jumlah pakan yang sisa pada hari tersebut;

3. Pertambahan bobot badan (g ekor minggu ${ }^{-1}$ ) diperoleh dari hasil perhitungan antara bobot badan akhir dikurangi bobot badan awal kemudian dibagi 12 minggu; dan

4. Konversi pakan diukur dengan menghitung rataan konsumsi pakan (g ekor minggu ${ }^{-1}$ ) dibagi dengan rataan

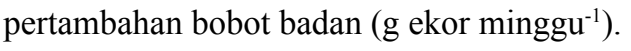

\section{Analisis Data}

Data dari tahap II dianalisis dengan hasil genotyping pada tahap I. Data dianalisis dengan menggunakan uji $t$ (Siregar 2017) :

$$
t=\frac{\bar{x}_{1}+\bar{x}_{2}}{\sqrt[s]{\frac{1}{n_{1}}+\frac{1}{n_{2}}}}
$$

$$
s=\sqrt{\frac{\sum_{i=1}^{n}\left(\bar{x}_{i}+\bar{x}_{1}\right)^{2}+\sum_{i=1}^{n}\left(\bar{x}_{i}+\bar{x}_{2}\right)^{2}}{n_{1}+n_{2}-2}}
$$

Keterangan:

dan $=$ rataan sifat produksi genotipe 1 dan 2

dan $=$ jumlah individu genotipe 1 dan 2

$\mathrm{s} \quad=$ standar deviasi

\section{HASIL DAN PEMBAHASAN}

\section{Genotipe Gen TGF-ß2 pada Ayam Tolaki}

Gen TGF- $\beta 2$ pada ayam terletak di kromosom 3. Berdasarkan data pada GenBank (dengan nomor akses : NC_006090.5) gen TGF- $\beta 2$ ini berukuran 64065 pb. Berdasarkan strukturnya, gen TGF- $\beta 2$ terdiri dari wilayah promotor, exon, intron dan flanking region. Struktur dari gen TGF- $\beta 2$, diawali oleh wilayah promotor yang berukuran 600 pb. Gen TGF- $\beta 2$ memiliki 7 exon dan 6 intron. Exon tersebut adalah $1,2,3,4,5,6$, dan 7 , yang masing-masing berukuran $391 \mathrm{pb}, 163 \mathrm{pb}, 132 \mathrm{pb}, 110 \mathrm{pb}, 174 \mathrm{pb}, 153$ $\mathrm{pb}, 3443 \mathrm{pb}$. Intron 1, 2, 3, 4, 5, dan 6, masing-masing berukuran 38631 pb, 14775 pb, 117 pb, 2184 pb, 559 pb, dan 2033 pb. Struktur gen TGF- $\beta 2$ diakhiri oleh flanking region yang berukuran $600 \mathrm{pb}$. Struktur dan ukuran gen TGF- $\beta 2$ disajikan pada Tabel 1 dan Gambar 2.

Tabel 1. Struktur dan ukuran gen TGF- $\beta 2$

\begin{tabular}{ccc}
\hline No & Struktur gen TGF- $\beta 2$ & Ukuran $(\mathrm{pb})$ \\
\hline 1 & Promotor & 600 \\
2 & Exon 1 & 391 \\
3 & Intron 1 & 38631 \\
4 & Exon 2 & 163 \\
5 & Intron 2 & 14775 \\
6 & Exon 3 & 132 \\
7 & Intron 3 & 117 \\
8 & Exon 4 & 110 \\
9 & Intron 4 & 2184 \\
10 & Exon 5 & 174 \\
11 & Intron 5 & 559 \\
12 & Exon 6 & 153 \\
13 & Intron 6 & 2033 \\
14 & Exon 7 & 3443 \\
15 & Flanking region & 600 \\
\hline
\end{tabular}

GeneBank (NC_006090.5)

Genotyping gen TGF- $\beta 2$ dilakukan pada exon 1, dengan produk PCR berukuran 284 pb. Adapun hasil visualisasi hasil elektroforesis dari penelitian ini disajikan dalam Gambar 3. Hasil pemotongan gen TGF- $\beta 2$ dengan enzim restiksi $R s a$ I berhasil mengidentifikasi 2 alel yaitu $\mathrm{T}$ dan C. Kedua Alel tersebut menghasilkan 3 genotipe yaitu TT, TC, dan CC (Gambar 3). Alel T memiliki 1 pita yaitu 284 pb. Alel C memiliki 2 pita yaitu 184 pb dan 100 pb. Kombinasi Alel T dan C memiliki 3 pita yaitu 284 pb, 184 pb dan $100 \mathrm{pb}$. 


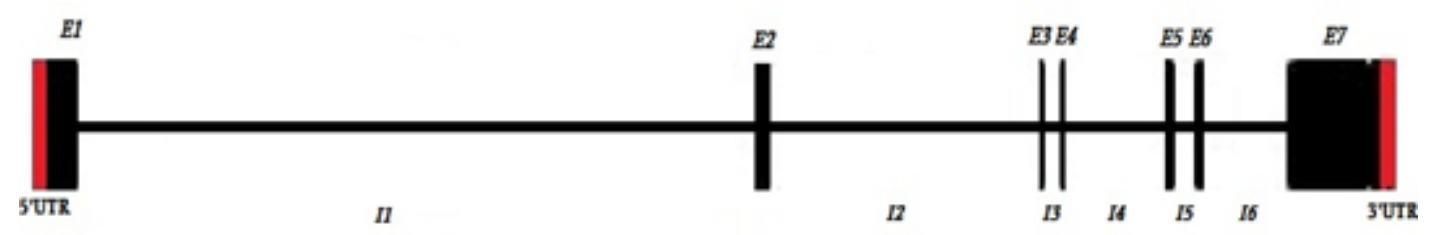

Gambar 2. Struktur gen TGF- $\beta 2$

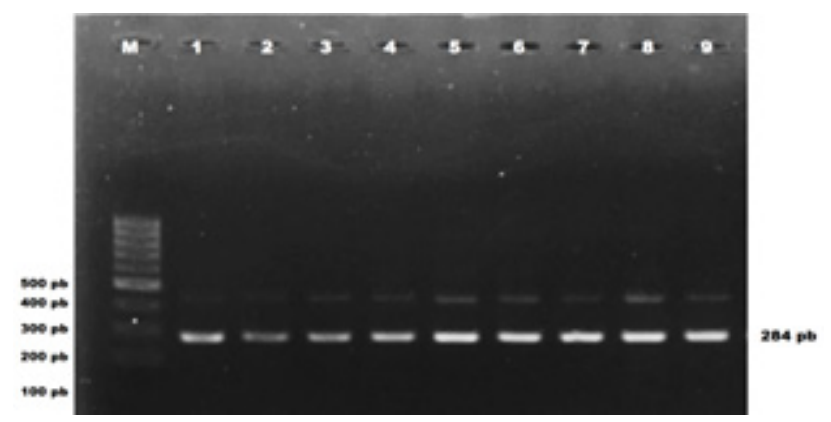

Gambar 3. Visualisasi hasil amplifikasi fragmen gen TGF- $\beta 2$ pada ayam tolaki dengan menggunakan gel agarosa $1.5 \%(\mathrm{M}=$ marker DNA $100 \mathrm{bp} ; 1-8=$ sampel DNA Ayam Tolaki)

Mutasi pada g.640 T>C menyebabkan situs enzim restriksi $R s a$ I yaitu GT|AC menjadi GC|AC. Hal tersebut sesuai dengan hasil penelitian yang dilakukan oleh Tohidi et al. (2012) bahwa SNP pada exon 1 gen TGF- $\beta 2$ merupakan substitusi antara basa thymine menjadi cytosine $(\mathrm{T} \rightarrow \mathrm{C})$ pada posisi 640. Mutasi tersebut merupakan mutasi synonimous karena kedua kodon (GTA dan GCA) menghasilkan asam amino yang sama yaitu alanine. Mutasi synonymous adalah mutasi yang tidak menyebabkan perubahan skuens asam amino dari sebuah protein, sehingga tidak dapat dideteksi pada tingkat asam amino. Namun, mutasi synonimous tidak selalu bersifat silent mutation, sebagai contoh mutasi tersebut dapat menciptakan situs splicing baru atau menghapuskan situs splicing yang sudah ada sehingga suatu sekuens exon berubah menjadi intron dan menyebabkan diproduksinya polipeptida yang berbeda (Li dan Graur 1991).

\section{Frekuensi Alel dan Genotipe Gen TGF-ß2}

Nilai frekuensi alel dan frekuensi genotipe gen TGF- $\beta 2$ pada lokus $R s a$ I pada ayam tolaki disajikan pada Tabel 2. Alel adalah bentuk alternatif dari gen yang memiliki lokus (posisi pada kromosom) yang sama, tetapi memiliki pengaruh yang berbeda. Hasil RFLP menggunakan enzim RsaI pada fragmen gen TGF- $\beta 2$ berhasil mengidentifikasi 2 alel yaitu alel $\mathrm{T}$ dan $\mathrm{C}$. Alel $\mathrm{T}$ mendominasi frekuensi alel gen TGF- $\beta 2$. Nilai frekuensi alel T secara keseluruhan pada ayam tolaki berkisar antara 0.77-0.81. Nilai frekuensi alel $\mathrm{C}$ berkisar antara 0.19-0.23. Hasil penelitian ini dapat diartikan bahwa gen TGF- $\beta 2$ pada lokus RsaI bersifat polimorfik (beragam). Hal ini sesuai dengan Allendroft et al. (2013) yang menyatakan bahwa suatu populasi dapat dikatakan memiliki sifat polimorfik jika frekuensi alelnya kurang dari 0.99 .

Genotipe adalah susunan genetik dari suatu sifat atau karakter individu. Pada penelitian ini, gen TGF- $\beta 2$ pada ayam tolaki teridentifikasi 3 macam genotipe, yaitu TT, TC, dan CC. Frekuensi genotipe tertinggi di setiap perlakuan terdapat pada genotipe TT dan terendah adalah genotipe CC. Hal ini menunjukkan bahwa genotipe TT pada ketiga populasi tersebut memiliki peluang kemunculan tertinggi dibandingkan dengan genotipe CC. Hasil yang sama dilaporkan oleh Tang et al. (2010), Niarami et al. (2014) dan Muhsinin et al. (2017) yang memperoleh 3 genotipe (TT, TC, dan CC) dari hasil pemotongan gen TGF- $\beta 2$ lokus RsaI. Lebih lanjut Muhsinin (2017) melaporkan frekuensi genotipe TT, TC, dan CC secara berurutan adalah 0.48 , 0.25 , dan 0.27 .

\section{Keseimbangan Genotipe Gen TGF- $\beta 2$ dalam Populasi}

Keseimbangan gen TGF- $\beta 2$ dalam populasi (keseimbangan Hardy-Weinberg) diuji dengan chi-square ). Uji chi-square digunakan untuk mengetahui populasi berada dalam keseimbangan Hardy-Weinberg. Nilai chi-square yang tidak signifikan pada taraf 5\% menunjukkan adanya

Tabel 2. Frekuensi alel, frekuensi genotipe dan keseimbangan Hardy-Weinberg gen TGF - $\beta 2$

\begin{tabular}{|c|c|c|c|c|c|c|c|}
\hline \multirow[t]{2}{*}{ Jenis Kelamin } & \multirow[t]{2}{*}{$\mathrm{N}$} & \multicolumn{2}{|c|}{ Frekuensi Alel } & \multicolumn{3}{|c|}{ Frekuensi Genotipe } & \multirow[t]{2}{*}{$\chi^{2}$} \\
\hline & & $\mathrm{T}$ & $\mathrm{C}$ & TT (n) & $\mathrm{TC}(\mathrm{n})$ & $\mathrm{CC}(\mathrm{n})$ & \\
\hline Jantan & 22 & 0.77 & 0.23 & $0.59(13)$ & $0.36(8)$ & $0.05(1)$ & 0.03 \\
\hline Betina & 48 & 0.81 & 0.19 & $0.67(32)$ & $0.29(14)$ & $0.04(2)$ & 0.09 \\
\hline Unsex & 70 & 0.80 & 0.20 & $0.64(45)$ & $0.31(22)$ & $0.04(3)$ & 0.02 \\
\hline
\end{tabular}

$\mathrm{n}=$ jumlah individu 


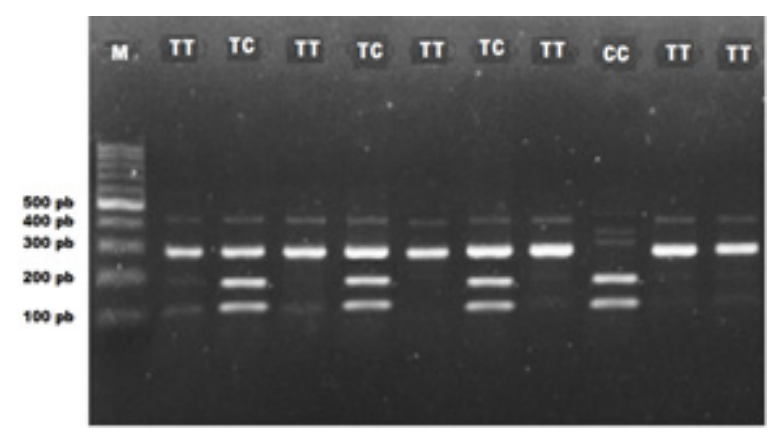

Gambar 4. Visualisasi hasil PCR-RFLP fragmen gen TGF- $\beta 2$ dengan menggunakan gel agarosa 2\% $(\mathrm{M}=$ marker DNA $100 \mathrm{bp})$

kesesuaian antara nilai pengamatan dan nilai harapan. Populasi dikatakan berada dalam keseimbangan jika nilai hitung lebih kecil dibandingkan dengan tabel (Allendorf et al. 2013). Hasil yang didapatkan pada populasi ayam tolaki menunjukkan bahwa berada dalam keseimbangan HardyWeinberg.

Allendorf et al. (2013), suatu populasi ternak dinyatakan berada dalam keseimbangan apabila frekuensi alel dan frekuensi genotipenya konstan dari generasi ke generasi yang diakibatkan oleh penggabungan gamet yang terjadi secara acak dalam populasi yang besar. Populasi yang cukup besar tidak akan berubah dari 1 generasi ke generasi lainnya jika tidak ada seleksi, migrasi, mutasi dan genetic drift (Noor 2008).
Keseimbangan genotipe gen TGF- $\beta 2$ pada lokus RsaI pada ayam tolaki ini, memperlihatkan bahwa intersitas kejadian mutasi, seleksi yang intensif serta migrasi bisa dikatakan rendah. Ayam tolaki selama ini dipelihara masyarakat secara ekstensif (diumbar), hal ini memungkinkan terjadinya perkawinan secara acak dari generasi ke generasi.

\section{Asosiasi Gen TGF- $\beta 2$ dengan Sifat Pertumbuhan}

Analisis yang dilakukan selanjutnya yaitu asosiasi antara gen TGF- $\beta 2$ dengan sifat pertumbuhan meliputi: bobot tetas, konsumsi pakan, bobot badan, pertambahan bobot badan dan konversi pakan disajikan pada Tabel 3 .

Gen TGF- $\beta 2$ adalah kelompok gen GH yang memainkan peran penting dalam diferensiasi sel,

Tabel 3. Asosiasi gen TGF- $\beta 2$ dengan bobot tetas, bobot badan, pertambahan bobot badan, konsumsi pakan, dan konversi pakan pada ayam tolaki

\begin{tabular}{lccc}
\hline Parameter & TT (n) & TC (n) & CC (n) \\
\hline Bobot Tetas $\left(\right.$ g ekor $\left.^{-1}\right)$ & $29.46 \pm 6.41(13)$ & $24.75 \pm 3.99(8)$ & $27.00 \pm 0.00(1)$ \\
Jantan & $24.88 \pm 4.43(32)$ & $25.86 \pm 5.05(14)$ & $26.00 \pm 1.41(2)$ \\
Betina & $26.20 \pm 5.43(45)$ & $25.45 \pm 4.63(22)$ & $26.33 \pm 1.15(3)$ \\
Unsex & & & $2734.35 \pm 0.00(1)$ \\
Konsumsi Pakan $\left(\mathrm{g} \mathrm{ekor}^{-1}\right)$ & $2590.42 \pm 20.64(13)$ & $2616.85 \pm 33.57(8)$ & $2677.85 \pm 23.33 \mathrm{a}(2)$ \\
Jantan & $2491.35 \pm 36.83 \mathrm{~b}(32)$ & $2547.16 \pm 64.26 \mathrm{~b}(22)$ & $2696.68 \pm 36.56 \mathrm{a}(3)$ \\
Betina & $2519.97 \pm 55.98 \mathrm{~b}(45)$ & & $556.00 \pm 0.00(1)$ \\
Unsex & & $483.00 \pm 25.63 \mathrm{~b}(14)$ & $537.50 \pm 26.16 \mathrm{a}(2)$ \\
Bobot Badan $\left(\mathrm{g} \mathrm{ekor}^{-1}\right)$ & $511.92 \pm 5.82(13)$ & $496.50 \pm 27.99 \mathrm{~b}(22)$ & $543.67 \pm 21.36 \mathrm{a}(3)$ \\
Jantan & $482.50 \pm 24.34 \mathrm{~b}(32)$ & & \\
Betina & $491.00 \pm 24.67 \mathrm{~b}(45)$ & $495.38 \pm 10.11(8)$ & $529.00 \pm 0.00(1)$ \\
Unsex & & $457.14 \pm 23.16 \mathrm{~b}(14)$ & $511.50 \pm 27.58 \mathrm{a}(2)$ \\
PBB $\left(\mathrm{g}\right.$ ekor $\left.{ }^{-1}\right)$ & $482.46 \pm 7.38(13)$ & $471.05 \pm 26.84 \mathrm{~b}(22)$ & $511.50 \pm 27.58 \mathrm{a}(3)$ \\
Jantan & $457.63 \pm 22.15 \mathrm{~b}(32)$ & & $4.92 \pm 0.00(1)$ \\
Betina & $464.80 \pm 22.14 \mathrm{~b}(45)$ & $5.03 \pm 0.15(8)$ & $4.99 \pm 0.29(2)$ \\
Unsex & & $5.21 \pm 0.29(14)$ & $4.97 \pm 0.21(3)$ \\
Konversi Pakan & $5.06 \pm 0.06(13)$ & $5.14 \pm 0.26(22)$ & \\
Jantan & $5.18 \pm 0.29(32)$ & $5.14 \pm 0.25(45)$ & \\
Betina & & \\
Unsex & & &
\end{tabular}

Angka-angka pada baris yang sama yang diikuti oleh huruf yang sama tidak berbeda nyata pada taraf uji $5 \% ; n=$ jumlah individu; PBB $=$ pertambahan bobot badan 
perkembangan otot dan pertumbuhan (Dunker dan Kreiglstein 2002). Gen TGF- $\beta 2$, selain termasuk kelompok gen $\mathrm{GH}$, juga termasuk kelompok gen sitokin (Susan 2011). Sitokin merupakan jenis protein yang terlibat dalam komunikasi sel-sel sebagai mediator untuk meningkatkan respon imun (Wibawan dan Soejoedono 2013). Mutasi gen TGF- $\beta 2$ secara signifikan $(p<0.05)$ berasosiasi dengan sifat pertumbuhan ayam tolaki. Pada gen TGF- $\beta 2$ genotipe CC memiliki konsumsi pakan, bobot badan dan pertambahan bobot badan yang lebih besar dibandingkan dengan genotipe TC dan TT (Tabel 3). Penelitian yang dilakukan oleh Bennett et al. (2007) bahwa hasil RFLP pada gen TGF- $\beta 2$ ditemukan 3 genotipe yakni TT, TC, dan CC pada ayam broiler. Genotipe $\mathrm{CC}$ memiliki nilai bobot badan ayam broiler umur 1-6 minggu yang lebih tinggi dibanding TC dan TT. Niarami et al. (2014) tampilan karkas ayam broiler pada genotipe CC dan TC memiliki persentase yang lebih besar dibanding pada genotipe TT. Hasil penelitian Tang et al. (2010) gen TGF- $\beta 2$ berasosiasi dengan bobot badan ayam lokal cina. Gen ini juga berasosiasi dengan komponen karkas ayam broiler (Li et al. 2003). Selain itu, gen TGF- $\beta 2$ berasosiasi dengan sifat ketahanan tubuh ayam terhadap Salmonella entritidis dan Salmonella pullorum (Tohidi et al. 2012; Muhsinin et al. 2017). Gen TGF- $\beta 2$ mempunyai ekspresi yang tinggi pada ayam broiler (Carlos et al. 2014).

\section{KESIMPULAN}

Gen TGF- $\beta 2$ pada ayam tolaki bersifat polimorfik dan ditemukan tiga genotipe (TT, TC, dan CC). Genotipe CC memiliki konsumsi pakan, bobot badan, pertambahan bobot badan yang lebih tinggi dan konversi pakan lebih efisien dibandingkan genotipe TC dan TT.

\section{DAFTAR PUSTAKA}

Aku, A.S., \& M. A. Pagala. 2010. Studi sebaran dan pemetaan populasi ayam tolaki (Manu ndolaki) di Kabupaten Kolaka dan Kolaka Utara dalam rangka pelestarian plasma nutfah asli Sulawesi Tenggara. Warta-wiptek. 18(1): 32-37.

Allendroft, F. W., G. Luikart, \& S. N. Aitken. 2013. Conservation and The Genetics of Populations. Ed ke2. Oxford (UK): Blackwell Publishing.

Bennett, A. K., P. Y. Hester, \& D. M. Spurlock. 2007. Relation of a transforming growth factor- $\beta 2$ single nucleotide polymorphism and messenger ribonucleic acid abundance with bone and production traits in chickens. Poultry Science 86:829-834.

Dunker, N., \& K. Krieglstein. 2002. TGF- $\beta 2$-/- TGF- $\beta 3$ $-/$ - double knockout mice display severe midline fusion defects and early embryonic lethality. Anat Embryol (Berl). 206:73-83

Hartl, D. L., \& A. G. Clark. 1997. Principle of Population Genetic. Sunderland (UK): Sinauer Associates, (MA).

Kramer, J., M. Malek, \& S. J. Lamont. 2003. Association of twelve candidate gene polymorphisms and response to challenge with Salmonella enteritidis in poultry. Anim Genet. 34(5): 339-348.

Li, W.H., \& D. Graur. 1991. Fundamentals of Molecular Evolution. Sunderland (GB): Sinauer.

Muhsinin, M, N. Ulupi, A. Gunawan, I. Wibawan, \& C. Sumantri. 2017. g. 640T> C Polymorphism of the TGF- $\beta 2$ gene is associated with Salmonella pullorum resistance in Indonesian chickens. Animal Production 19(2):81-92.

Nafiu, L.O., A. S. Aku, T. Saili, Y. Taufik, \& M. Rusdin. 2009. Pelestarian dan pengembangan ayam tolaki sebagai plasma nutfah asli Sulawei Tenggara. Laporan Penelitian. Kendari (ID): Lembaga Penelitian Unhalu.

Nafiu, L.O., M. Rusdin, \& A. S. Aku. 2012. Produksi dan karakteristik telur ayam tolaki pada pemeliharaan intensif. Agriplus. 22 (3): 207-214.

[NCBI] National Center for Biotechnology Information. 2018. Gene TGF- $\beta 2$. [terhubung berkala] http,s://www. ncbi.nlm.nih.gov/gene/421352 [09 September 2018].

Nei, M., \& S. Kumar. 2000. Molecular Evolution and Phylogenetics. New York (US): Oxford University Press.

Niarami, D., Mojtaba, A. A. Masoudi, \& R. V. Torshizi. 2014. Association of single nucleotide polymorphism of GHSR and TGF- $\beta 2$ genes with growth and body composition traits in sire and dam lines of a broiler chicken. Animal biotechnology 25(1): 13-22.

Noor, R. R. 2008. Genetika Ternak. Jakarta (ID): Penebar Swadaya.

Pagala, M.A., A. S. Aku, R. Badaruddin, \& H. Has. 2018. Karakteristik fenotip dan genotip gen cGH pada ayam tolaki. JITRO. 5(3): 1-5.

Pagala, M.A., Muladno, C. Sumantri, \& S. Murtini. 2013. Association of Mx gene genotype with antiviral and production traits in tolaki chicken. International 
Journal of Poultry Science 12(12): 735-739.

Rusdin M, L. O. Nafiu, T. Saili, \& A. S. Aku. 2011. Karakteristik fenotipe sifat kualitatif ayam tolaki di Kabupaten Konawe Sulawesi Tenggara. Agriplus 21(3): 248-256.

Sambrook, J., \& D. Russell. 2001. Molecular Cloning: a Laboratory Manual. $3 \mathrm{rd}$ ed. New York (US): Cold Spring Harbor Laboratory Press.

Sartika, T. 2012. Ketersediaan sumberdaya genetik ayam lokal dan strategi pengembangannya untuk pembentukan parent dan grand parent stock. Prosiding Workshop Nasional Unggas Lokal. Jakarta (ID): Balai Penelitian Ternak.

Siregar S. 2017. Metode Penelitian Kuantitatif : Dilengkapi dengan Perbandingan Perhitungan Manual dan SPSS. Jakarta (ID): PT Fajar Interpratama Mandiri.

Sulandari, S., M. S. A. Zein, S. Paryanti, \& T. Sartika. 2007. Taksonomi dan asal usul ayam domestikasi. Dalam buku Keragaman Sumber Daya Hayati Ayam Lokal Indonesia:Manfaat dan Potensi. Editor: Kusumo Diwyanto dan Siti Nuramaliati Prijono. Bogor (ID): Pusat Penelitian Biologi, LIPI.
Susan, J.I. 2011. Salmonella in Chicken : Breeding for Disease Resistance in Farm Animal. 3 rd Ed. Cambridge (USA). CAB International.

Tang, S., J. Ou, D. Sun, Y. Zhang, G. Xu, \& Y. Zhang. 2011. A novel $62 \mathrm{bp}$ indel mutation in the promoter region of transforming growth factor-beta 2 (TGF- $\beta 2$ ) gene is associated with body weight in chickens. Animal genetics 42(1): 108-112.

Tohidi, R., I. Idris, J. M. Panandam, \& M. H. Bejo. 2012. The effects of polymorphisms in IL-2, IFN- $\gamma$, TGF- 32 , IgL, TLR-4, MD-2, and iNOS genes on resistance to Salmonella Enteritidis in indigenous chickens. Avian Pathol. 41(6), 605-612.

Wibawan, I. W. T., \& R.S. Soejoedono. 2013. Intisari Imunologi Medis. Bogor (ID): Institut Pertanian Bobor. 